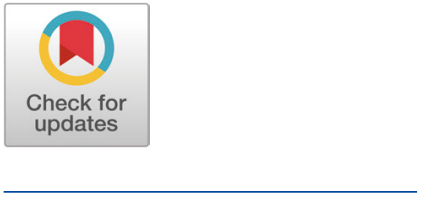

Received: Feb 15, 2020

Revised: Apr 1, 2020

Accepted: May 6, 2020

$\#_{\text {These authors contributed equally to }}$ this work.

*Corresponding author

Ram Singh

ICAR-Central Institute for Research on Buffaloes, Hisar 125001 (Haryana), India.

Tel: +91-9457602079

E-mail: carirsingh@yahoo.co.in

Balamuralikrishnan Balasubramanian Department of Food Science and Biotechnology, College of Life Science, Sejong University, Seoul 05006, Korea. Tel: +82-2-6935-2612

E-mail: bala.m.k@sejong.ac.kr

Copyright () 2020 Korean Society of Animal Sciences and Technology. This is an Open Access article distributed under the terms of the Creative Commons Attribution

Non-Commercial License (http:// creativecommons.org/licenses/bync/4.0/) which permits unrestricted non-commercial use, distribution, and reproduction in any medium, provided the original work is properly cited.

ORCID

Ram Singh

https://orcid.org/0000-0002-8251-8625

\section{Significance of varying concentra- tions of T-2 toxin on growth performance, serum biochemical and hematological parameters in broiler chickens}

\author{
Ram Singh ${ }^{1 \# *}$, Sungkwon Park ${ }^{2}$, Jin Su Koo ${ }^{2}$, In $\mathrm{Ho} \mathrm{Kim}^{3}$ and \\ Balamuralikrishnan Balasubramanian ${ }^{2 \#_{*}}$ \\ ${ }^{1}$ ICAR-Central Institute for Research on Buffaloes, Hisar 125001 (Haryana), India \\ ${ }^{2}$ Department of Food Science and Biotechnology, College of Life Science, Sejong University, Seoul \\ 05006, Korea \\ ${ }^{3}$ Department of Animal Resource and Science, Dankook University, Cheonan 31116, Korea
}

\section{Abstract}

The study was to determine the effects of diverse concentrations of T-2 toxin in broiler diet. Three hundred 1-day-old chicks with initial body weight of $46 \pm 0.52 \mathrm{~g}$ were chosen and randomly assigned into five dietary treatments with 5 replicate cages and 12 broilers per cage for $42 \mathrm{~d}$ feeding trial. Dietary treatments were prepared with basal diets containing $0\left(T_{1}\right), 50$ $\left(T_{2}\right), 100\left(T_{3}\right), 150\left(T_{4}\right), 200\left(T_{5}\right)$ ppb T2-toxin. Significant results were observed in the decreased intake of feed, feed conversion ratio (FCR), body weight gain (BWG), level of serum protein, cholesterol and hemoglobulin of broilers in increased concentration of the T-2 toxin in diet (150 and $200 \mathrm{ppb}$ ) groups than control. Also, observed that the uric acid, serum glutamic pyruvic transferase (SGPT), serum glutamic oxaloacetic transferase (SGOT) and Heterophil/ Lymphocyte $(H / L)$ ratio value were significantly higher $(p<0.05)$ in groups $T_{4}$ and $T_{5}$ than control. However, the BWG, feed intake and FCR, as well blood biochemical profiles of serum protein, cholesterol, hemoglobulin, uric acid, SGPT, SGOT and H/L ratio in groups $T_{2}$ and $\mathrm{T}_{3}$ were statistically similar to control diet of broilers. It was concluded that the results showed that no adverse effects on growth performance and blood biochemical parameters in broilers feed with T-2 toxin (50 and $100 \mathrm{ppb}$ ) during the entire trial.

Keywords: Biochemical profile, Growth performance, Indian river broilers, Tolerance level, T-2 toxin

\section{INTRODUCTION}

Mycotoxins are produced by filamentous fungi, which fall under the genus Aspergillus, Claviceps, Penicillium, Alternaria, and Fusarium. These species have the capacity to grow on foods during favorable conditions such as temperature, moisture content, relative humidity and water activity. The Fusarium 
Sungkwon Park

https://orcid.org/0000-0002-7684-9719

Jin Su Koo

https://orcid.org/0000-0002-7435-2194

In Ho Kim

http://orcid.org/0000-0001-6652-2504

Balamuralikrishnan Balasubramanian

https://orcid.org/0000-0001-6938-1495

Competing interests

No potential conflict of interest relevant to

this article was reported.

Funding sources

Not applicable.

Acknowledgements

Authors would like to thankful to the National

Research Foundation of Korea for their

support through Basic Science Research

Program in Ministry of Science and

Education (Grant No: 2018R1C1B5086232).

Availability of data and material Upon reasonable request, the datasets of this study can be available from the corresponding author.

Authors' contributions

Conceptualization: Singh R, Balasubramanian B.

Data curation: Singh $R$.

Formal analysis: Singh R, Koo JS,

Balasubramanian B.

Methodology: Singh R.

Software: Singh R, Koo JS.

Investigation: Singh R.

Writing - original draft: Singh $\mathrm{R}$

Balasubramanian B.

Writing - review \& editing: Singh R, Park S,

Koo JS, Kim IH, Balasubramanian B.

Ethics approval and consent to participate The experimental protocol (P-1/2010/1-IAV/ L-34/3745/6000) for this study was reviewed and approved by the Animal Care and Use Committee of ICAR-Central Avian Research Institute, India. mycotoxins are capable of produce acute and chronic toxic effects, depends on their concentration, exposure time and the type of animal that is exposed and its age [1]. One of the most important trichothecene mycotoxin affecting poultry production is T- 2 toxin and naturally produced by Fusarium $[2,3]$. The name trichothecenes was derived from the skeletal tetracycline in their molecule, 12 , 13-epoxyitricotec-9-eno. The main effect of trichothecenes toxins is distract the normal functions of gastro-enteric system, also affecting the digestive, the nerves, circulatory systems, as well as skin. The T-2 toxin is found in many cereals, feeds, and vegetables. Several types of grains have been tested for the contamination with T-2 toxin and as a result, rye, wheat, oat, corn and barley are found to be frequently contaminated [4]. The negative effects of T-2 toxin in poultry, leads to reduced consumption in feed, growth depression, oral lesions [5,6], decreased egg production, thickness egg shells, hatchability and coagulopathy [5], abnormal feathering [7]. Therefore, the aim of the present study was to evaluate the effects of various concentrations of T-2 toxin in diets in the broilers.

\section{MATERIALS AND METHODS}

All experiments and protocols (P-1/2010/1-IAV/L-34/3745/6000) were approved by the Animal Ethics Committee of Research Institute from ICAR-Central Avian Research Institute, Izatnagar, India. Appropriate guidelines and protocols were followed for all experiments.

\section{Mycotoxin production and analysis}

The T-2 toxin was formed on the maize substrate by means of the pure culture of Fusarium sporotrichioides NRRL 3510 (USDA/ARS Culture Collection, National Center for Agricultural Utilization Research, Peoria, IL, USA). Then T-2 toxin was extracted by the method of Rukmini and Bhat [8] and quantified by thin layer chromatography as described by Mandal et al. [28]. The required amount was added to the basal diet to get the desired concentration of T-2 toxin in feed. An analyzed T-2 toxin content of the diets were the same as predicted concentration with variations of \pm 2 ppb.

\section{Experimental design, birds and husbandry}

A total of three hundred 1-day-old healthy Indian River-3 broiler chicks (mixed gender) were obtained from experimental hatchery (ICAR-Central Avian Research Institute, Izatnagar, India). Birds with a mean body weight of $46 \pm 0.52 \mathrm{~g}$ were randomly assigned to 5 dietary treatments ( 5 replicate cages/treatment, 12 chicks/cage) for 42 days of trial. Birds were housed in stainless steel cages $(1.75 \times 1.55 \mathrm{~m})$ with environmental controlled room, with free access to feed and water. The dietary treatments include the following: basal diet $\left(\mathrm{T}_{1}\right)$, basal diet contaminated with 50 (T2), $100\left(\mathrm{~T}_{3}\right), 150\left(\mathrm{~T}_{4}\right)$, and $200\left(\mathrm{~T}_{5}\right)$ ppb T2-toxin for feeding trial. The basal diets were formulated to exceed the nutritional necessities of broilers through starter ( $\mathrm{d} 0$ to 21 ) and finisher ( $\mathrm{d} 22$ to 42 ) phases, according to NRC [10] recommendations (Table 1).

\section{Sampling and measurements}

The feed samples were passed through the screen which is in size of $1 \mathrm{~mm}$ for the analysis of calcium (Ca, method: 984.27) and phosphorus (P, method: 965.17) contents according to AOAC [9] methods. The concentrations of lysine, methionine, available $\mathrm{P}$ and metabolizable energy were calculated.

Broilers were weighed and the feed intake was recorded at day 1,21, and 42. Determination of body weight gain (BWG, g), average daily feed intakes (ADFI, g) and feed conversion ratio (FCR) were calculated in each phase. At the end of the experiment, about $5 \mathrm{~mL}$ of blood samples were 
Table 1. Ingredients and chemical composition of basal diet

\begin{tabular}{|c|c|c|}
\hline Item & Starter (\%) & Finisher (\%) \\
\hline \multicolumn{3}{|l|}{ Ingredient (\%) } \\
\hline Corn & 55.505 & 61.715 \\
\hline Soybean meal & 41 & 35 \\
\hline Limestone & 1 & 1.1 \\
\hline Di-calcium phosphate & 1.75 & 1.5 \\
\hline Common salt & 0.3 & 0.3 \\
\hline DL-Methionine & 0.11 & 0.02 \\
\hline Minerals premix ${ }^{1}$ & 0.1 & 0.1 \\
\hline Vitamin premix ${ }^{2)}$ & 0.15 & 0.15 \\
\hline B complex ${ }^{3)}$ & 0.015 & 0.015 \\
\hline Choline chloride & 0.05 & 0.05 \\
\hline \multicolumn{3}{|l|}{ Calculated composition } \\
\hline Metabolizable energy (MJ/kg) & 12.52 & 12.84 \\
\hline \multicolumn{3}{|l|}{ Analyzed composition (\%) } \\
\hline Crude protein & 21.50 & 19.50 \\
\hline Calcium & 1.04 & 0.99 \\
\hline Ether extract & 3.79 & 3.58 \\
\hline Available phosphorus & 0.45 & 0.40 \\
\hline Lysine & 1.29 & 1.14 \\
\hline Methionine & 0.52 & 0.43 \\
\hline \multicolumn{3}{|c|}{ 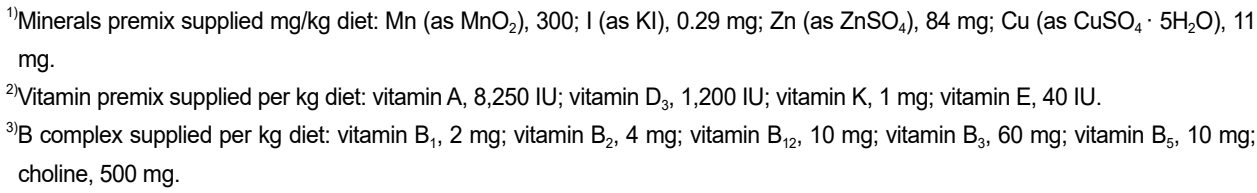 } \\
\hline
\end{tabular}

collected from 20 chickens of each treatment (4 broilers/cage) from wing vein, kept in vacuum tube or a $\mathrm{K}_{3} \mathrm{EDTA}$ tube followed by the centrifugation at $4,000 \mathrm{~g}$ at $4{ }^{\circ} \mathrm{C}$ for $15 \mathrm{~min}$, in order to collect the serum from the blood sample, and further stored at $-18^{\circ} \mathrm{C}$ until analysis. Serum samples were examined for total protein, uric acid, cholesterol, serum glutamic oxaloacetic transferase (SGOT), serum glutamic pyruvic transferase (SGPT) by using an automatic blood clinical analyzer (Chiron, San Jose, CA, USA). The hemoglobin ( $\mathrm{Hb}$ ) concentration in blood was estimated by Sahli's method [11]. By adding $0.1 \mathrm{~N} \mathrm{HCl}$, the $\mathrm{Hb}$ was converted into acid haematin. The resultant solution was then matched against a reference solution (i.e., Sahli's Haemoglobinometer). Reading on the graduated tube was noted and expressed as $\mathrm{Hb}$ level in $\mathrm{g} / \mathrm{dL}$. With regard to heterophil/lymphocyte $(\mathrm{H} / \mathrm{L})$ ratio, the percentage distribution of different leucocytes was determined from a blood smear stained with Giemsa stain. The blood smear was prepared in a clean and dry glass slide using anticoagulant added blood. The blood smears were fixed with methanol. Then, the blood smears were covered uniformly with enough Giemsa stain for about 30-45 mins. Afterwards, the stained blood smears were rinsed with running tap water and dried. The smears were observed under microscope by using an oil immersion objective lens after adding one or two drops of cedar wood oil on the stained blood smear. The percentage of different leucocytes was calculated after the count reaches 100 in leucocytes and the $\mathrm{H} / \mathrm{L}$ ratio was estimated by separating the number of heterophils by that of lymphocyte. 


\section{Statistical analysis}

The statistical analysis of all the collected data was performed using general linear model procedures of SAS/STAT (Statistical Analysis System, version 9.2, SAS Institute, Cary, NC, USA) in a randomized complete block design with a pen was considered as the experimental unit. Mean values and standard errors of the mean were reported. Linear and quadratic polynomial contrasts were performed to determine the effect of T-2 toxin at inclusion levels in the diet. Statistical significance was considered when probability value was less than 0.05 .

\section{RESULTS AND DISCUSSION}

The production performance of chickens by the T2-toxin presence has been presented in Table 2. During entire experiment, observed singnificantly reduced BWG and ADFI $(p<0.05)$ at level (200 ppb) of T-2 toxin diet when compared to the other groups. In the current study, the contamination in dietary treatments by $150 \mathrm{ppb}$ or higher levels of T-2 toxin led to a reduction in BWG and ADFI of broilers significantly $(p<0.05)$. This findings of a reduction in body weight and feed consumption were due to T-2 toxicosis consistent with earlier reports of feeding T-2 toxin $[7,12,13]$. Previous studies, have reported that the T-2 toxin has induced toxicity in the chicks in a dose dependent mode that resulted in reduced body weight in broilers [14-16]. Growth depression effects of mycotoxin appear to be primarily resulted by their inhibitory action on protein synthesis and nutrient utilization [17]. Also, the T-2 toxicated chicks have shown that the reduced body weight; may be due to inflammation or irritation and contact erosion in alimentary tract, which leads to the reduced feed consumption and subsequently the reduction in body weight of the birds [18-20]. The few studies conducted on poultry have indicated that the T-2 toxin has caused the decreased intake of feed and lower gain of weight, oral lesions, coagulopathy, changes in behaviour and the distorted feathering $[16,21-25]$. The observed results showed that the significantly lower $(p<0.05)$ FCR in control diet without T2-toxin, compared with other groups. The study revealed that the feed contaminated with T-2 toxin at $150 \mathrm{ppb}$ or higher level resulted in increased FCR which deteriorated

Table 2. Effect on T-2 toxin growth performance in broilers

\begin{tabular}{|c|c|c|c|c|c|c|c|c|}
\hline \multirow{2}{*}{ Items } & \multirow{2}{*}{$\mathrm{T}_{1}$} & \multirow{2}{*}{$\mathrm{T}_{2}$} & \multirow{2}{*}{$\mathrm{T}_{3}$} & \multirow{2}{*}{$\mathrm{T}_{4}$} & \multirow{2}{*}{$\mathrm{T}_{5}$} & \multirow{2}{*}{ SEM } & \multicolumn{2}{|c|}{$p$-value } \\
\hline & & & & & & & Linear & Quadratic \\
\hline \multicolumn{9}{|l|}{ Week 0-3 } \\
\hline ADFI (g) & $769.49^{a}$ & $764.77^{\mathrm{a}}$ & $745.96^{b}$ & $742.23^{b}$ & $705.02^{c}$ & 15.420 & 0.048 & 0.0239 \\
\hline FCR & $1.543^{b}$ & $1.552^{\mathrm{b}}$ & $1.541^{\mathrm{b}}$ & $1.601^{\mathrm{a}}$ & $1.629^{\mathrm{a}}$ & 0.046 & $<.0001$ & 0.0939 \\
\hline ADFI (g) & $2,022.88^{\mathrm{a}}$ & $2,012.49^{a}$ & $1,967.65^{\mathrm{a}}$ & $1,819.50^{b}$ & $1,703.67^{c}$ & 19.785 & $<.0001$ & $<.0001$ \\
\hline FCR & $1.562^{b}$ & $1.509^{b}$ & $1.556^{\mathrm{b}}$ & $1.584^{\mathrm{a}}$ & $1.572^{\mathrm{a}}$ & 0.033 & $<.0001$ & 0.0017 \\
\hline \multicolumn{9}{|c|}{ Overall (Week 0-6) } \\
\hline BWG (g) & $1,507.51^{\mathrm{a}}$ & $1,470.98^{a}$ & $1,451.73^{b}$ & $1,270.79^{c}$ & $1,170.54^{d}$ & 16.883 & $<.0001$ & $<.0001$ \\
\hline
\end{tabular}

Each mean represents values from 5 replicates (12 birds/replicate).

Control ( $T_{1}$, basal diet), basal diet supplemented with $50\left(T_{2}\right), 100\left(T_{3}\right), 150\left(T_{4}\right), 200\left(T_{5}\right)$ ppb T2-toxin for feeding trial.

${ }^{a-d}$ Means in the same row with different superscripts differ $(p<0.05)$.

SEM, standard error mean; BWG, body weight gain; ADFI, avergae daily feed intake; FCR, feed conversion ratio. 
feed efficiency of broilers. This result was in agreement with that Raju and Devegowda [7], reported that the inclusion of T-2 toxin ( $3 \mathrm{mg} / \mathrm{kg}$ feed) of has made poor feed conversion efficiency of the broilers. Further, the present study revealed that the T-2 toxin ranges up to $100 \mathrm{ppb}$ in broilers' diet had no adverse effect on their growth, feed consumption and feed conversion efficiency.

The data pertaining to various biochemical parameters such as total protein, SGPT, SGOT, uric acid, $\mathrm{Hb}$, cholesterol and $\mathrm{H} / \mathrm{L}$ ratio were influenced by different levels of $\mathrm{T}-2$ toxin was statistically analyzed and the mean values are presented in Table 3 . The total serum protein concentration of group $\mathrm{T}_{1}$ was higher $(p<0.05)$ than those of $\mathrm{T}_{4}$ and $\mathrm{T}_{5}$, but statistically similar to those of $\mathrm{T}_{2}$ and $\mathrm{T}_{3}$. The lowest total protein content was observed in group $\mathrm{T}_{5}(p<0.05)$ when compared to $\mathrm{T}_{4}$. The present study revealed that the dietary contamination of T-2 toxin at $150 \mathrm{ppb}$ or higher level resulted in significantly reduced $(p<0.05)$ on total protein content of broiler chickens. This results was in agreement with previous reports $[14,26]$ in literature wherein showed that the decreased serum protein concentration was proportional to dietary levels of T-2 toxin. Further, the results showed that the lower level of cholesterol and Hb levels, increased uric acid content, SGPT, SGOT and H/ $\mathrm{L}$ ratio $(p<0.05)$ in increases concentrations of $\mathrm{T}-2$ toxin $(150$ and $200 \mathrm{ppb})$ compared with other dietary treatments in broilers (Table 3). This finding was in agreement with earlier report of Pande et al. [14], who reported a reduction in serum cholesterol level, $\mathrm{Hb}$ and increased in serum uric acid due to a dietary T-2 toxin in broilers. The reduced levels of total serum protein and cholesterol, may be an effect of hepato-toxicity of T-2 toxin [14]. This increase in uric acid level may be due to the poor utilization of protein for the synthesis of tissue protein, rather than the reduced kidney function $[26,27]$. The reports of effects of the dietary T-2 toxin on activity of SGPT and SGOT in the broilers were in agreement with those of Narayanaswamy [29]; Krishnamoorthy [30]; Singh [31]. Contrary, Pande et al. [14] and Wyatt et al. [21] reported that a non-significant effects of T-2 toxin dietary treatments in graded levels on the $\mathrm{H} / \mathrm{L}$ ratio of broilers.

\section{CONCLUSION}

It can be stated that, the broiler chickens were less affected by 100 ppb T-2 toxin than other concentrations. This results suggested that the potentials impacts of T-2 toxin in broilers; however, further research are needed to determine the effects of $\mathrm{T}-2$ toxin on gut health and meat quality traits in broilers to achive great attention in current conventional system.

Table 3. Effect of T-2 toxin on blood biochemical parameters of broiler chickens

\begin{tabular}{|c|c|c|c|c|c|c|c|c|}
\hline \multirow{2}{*}{ Items } & \multirow{2}{*}{$\mathrm{T}_{1}$} & \multirow{2}{*}{$T_{2}$} & \multirow{2}{*}{$T_{3}$} & \multirow{2}{*}{$T_{4}$} & \multirow{2}{*}{$T_{5}$} & \multirow{2}{*}{ SEM } & \multicolumn{2}{|c|}{$p$-value } \\
\hline & & & & & & & Linear & Quadratic \\
\hline Total protein & $6.584^{a}$ & $6.698^{a}$ & $6.694^{\mathrm{a}}$ & $4.698^{b}$ & $4.172^{\mathrm{C}}$ & 0.049 & $<.0001$ & $<.0001$ \\
\hline Cholesterol & $197.748^{b}$ & $206.818^{a}$ & $209.91^{a}$ & $151.824^{c}$ & $144.412^{d}$ & 2.409 & $<.0001$ & $<.0001$ \\
\hline Uric acid & $6.362^{c}$ & $6.602^{b c}$ & $6.792^{b}$ & $7.888^{\mathrm{a}}$ & $8.034^{\mathrm{a}}$ & 0.107 & $<.0001$ & 0.0929 \\
\hline SGPT & $37.728^{b}$ & $39.068^{b}$ & $38.856^{b}$ & $52.61^{a}$ & $53.334^{a}$ & 1.157 & $<.0001$ & 0.0096 \\
\hline SGOT & $134.54^{c}$ & $136.626^{c}$ & $135.89^{c}$ & $224.816^{b}$ & $246.234^{a}$ & 2.895 & $<.0001$ & $<.0001$ \\
\hline $\mathrm{Hb}(\mathrm{g} / \mathrm{dL})$ & $8.354^{b}$ & $8.24^{\mathrm{a}}$ & $8.184^{\mathrm{ab}}$ & $5.418^{c}$ & $4.994^{d}$ & 0.119 & $<.0001$ & $<.0001$ \\
\hline $\mathrm{H} / \mathrm{L}$ ratio & $0.568^{\mathrm{b}}$ & $0.554^{b}$ & $0.564^{b}$ & $1.088^{a}$ & $1.068^{\mathrm{a}}$ & 0.0177 & $<.0001$ & $<.0001$ \\
\hline
\end{tabular}

Each mean represents values from 5 replicates (12 birds/replicate).

Control ( $T_{1}$, basal diet), basal diet supplemented with $50\left(T_{2}\right), 100\left(T_{3}\right), 150\left(T_{4}\right), 200\left(T_{5}\right)$ ppb T2-toxin for feeding trial.

${ }^{a-d}$ Means in the same row with different superscripts differ $(p<0.05)$.

SEM, standard error mean; SGPT, serum glutamic pyruvic transferase; SGOT, serum glutamic oxaloacetic transferase; H/L ratio, heterophil/lymphocyte ratio. 


\section{REFERENCES}

1. D'mello JPF, Placinta CM, MacDonald AMC. Fusarium mycotoxins: a review of global implications for animal health, welfare and productivity. Anim Feed Sci Technol. 1999;80:183-205.

2. Diaz DE. The mycotoxin blue book. 1st ed. Nottingham, UK: Nottingham University Press; 2005. p. 25-56.

3. Singh R, Mandal AB, Biswas A. Mycotoxicosis and its management in poultry [Internet]. Avian Nutrition and Feed Technology Division. Izatnagar, India: Central Avian Research Institute. 2019 [cited Apr 17 2020]. https://en.engormix.com/mycotoxins/articles/mycotoxicosis-its-management-poultry-t43390.htm

4. European Commission [EC]. Reports on tasks for scientific cooperation: collection of occurrence data of Fusarium toxins in food and assessment of dietary intake by the population of EU Member States [Internet]. 2003 [cited Apr 17 2020]. https://ec.europa.eu/food/sites/food/ files/safety/docs/cs_contaminants_catalogue_fusarium_task3210.pdf

5. Girish CK, Devegowda G. Efficacy of glucomannan containing yeast product (Mycosorb $\left.{ }^{\circledR}\right)$ and hydrated sodium calcium aluminosilicate in preventing the individual and combined toxicity of aflatoxin and T-2 toxin in commercial broilers. Asian-Australas J Anim Sci. 2006;19:87783.

6. Kubena LF, Harvey RB, Huff WE, Corrier DE, Phillips TD, Rottinghaus GE. Efficacy of hydrated sodium calcium aluminosilicate to reduce the toxicity of aflatoxin and T-2 toxin. Poult Sci. 1990;69:1078-86.

7. Raju MVLN, Devegowda G. Influence of esterified glucomannan on performance and organic morphology, serum biochemistry and hematology in broilers exposed to individual and combined mycotoxicosis (aflatoxin, ochratoxin, and T-2 toxin). Br Poult Sci. 2000;41:640-50.

8. Rukmini C, Bhat RV. Occurrence of T-2 toxin in Fusarium infested sorghum from India. J Agric Food Chem. 1978;26:647-9.

9. AOAC [Association of Official Analytical Chemists] International. Official methods of analysis of AOAC International. 16th ed. Washington, DC: AOAC International; 1995.

10. NRC [National Research Council]. Nutrient requirements of poultry. 9th ed. Washington, DC: National Academies Press; 1994.

11. Balasubramaniam P, Malathi A. Comparative study of hemoglobin estimated by Drabkin's and Sahli's methods.J Postgrad Med. 1992;38:8-9.

12. Nesic K, Resanovic R, Jakic-Dimic D, Nesic V. Efficiency of various feed additives on the performance of broilers treated with T-2 toxin. Biotechnol Anim Husb. 2011;27:705-11.

13. Arvind KL, Patil VS, Devegowda G, Umakantha B, Ganpule SP. Efficacy of esterified glucomannan to counteract mycotoxicosis in naturally contaminated feed on performance, serum biochemical and hematological parameters in broilers. Poult Sci. 2003;82:571-6.

14. Pande VV, Kurkure NV, Bhandarkar AG. Effect of T-2 toxin on growth, performance and haematobiochemical alterations in broilers. Indian J Exp Biol. 2006;44:86-8.

15. Natraja TH, Narayanaswamy HD, Santosh Kumar B, Prakash GC. Performance of broiler chickens in experimental Afla and T-2 toxicosis. Indian Vet Med J. 2004;28:40.

16. Wyatt RD, Hamilton PB, Burmeister HR. Altered feathering of chicks caused by T-2 toxin. Poult Sci. 1975;54:1042-5.

17. Hassan Z, Khan MZ, Khan A, Javed I. Pathological responses of white Leghorn breeder hens kept on ochratoxin A contaminated feed. Pak Vet J. 2010;30:118-23.

18. Bamberg JR, Strong FM. 12,13-epoxytrichothecenes. In: Kadis S, Ciegler A, Ajl SJ, editors. Microbial toxins, vol. 7. New York, NY: Academic Press; 1971. 
19. Hoerr FJ. Mycotoxicoses. In: Saif YM, editor. Diseases of poultry. 11th ed. Ames, IA: Iowa State University Press; 2003.p. 1103-32.

20. Chi MS, Mirocha CJ, Kurtz HF, Weaver G, Bates F, Shimoda W. Effects of T-2 toxin on reproductive performance and health of laying hens. Poult Sci. 1977;56:628-37.

21. Wyatt RD, Weeks BA, Hamilton PB, Burmister HR. Severe oral lesions in chickens caused by ingestion of dietary fusariotoxin T-2. Appl Environ Microbiol. 1972;24:251-7.

22. Doerr JA, Hamilton PB, Burmeister HR. T-2 toxicosis and blood coagulation in young chickens. Toxicol Appl Pharmacol. 1981;60:157-62.

23. Hoerr FJ, Carlton WW, Yagen B, Joffe AZ. Mycotoxicosis caused by either T-2 toxin or diacetoxyscirpenol in the diet of broiler chickens. Fundam Appl Toxicol. 1982;2:121-4.

24. Hoerr FJ, Carlton WW, Yagen B, Joffe AZ. Mycotoxicosis produced in broiler chickens by multiple doses of either T-2 toxin or diacetoxyscirpenol. Avian Pathol. 1982;11:369-83.

25. Huff WE, Harvey RB, Kubena LF Rottinghaus GE. Toxic synergism between aflatoxin and T-2 toxin in broiler chickens. Poult Sci. 1988;67:1418-23.

26. Indresh HC, Umakantha B. Effects of ochratoxin and T-2 toxin combination on performance, biochemical and immune status of commercial broilers. Vet World. 2013;6:945-9.

27. Coffin JL, Combs GF Jr. Impaired vitamin E status of chicks fed T-2 toxin. Poult Sci. 1981;60:385-92.

28. Mandal AB, Khatta VK, Biswas A, Sihag S, Singh R. Analytical techniques in animal nutrition. Delhi: Satish Serial Publishing House. 2018. p. 1-183.

29. Narayanaswamy HD. Pathology of Fusarium T-2 mycotoxicosis in broiler chickens [Ph.D. dissertation]. Chennai, India: Tamilnadu Veterinary and Animal Sciences University; 1998.

30. Krishnamoorthy P, Vairamuthu S, Balachandran C, Murali Manohar B. Chlorpyriphos and T-2 toxin induced haematobiochemical alteration in broiler chicken. Int J Poult Sci. 2006;5:173-7.

31. Singh R. Impact of varying levels of T-2 toxin on production performance and biochemical profile in Turkey poults. J Poult Sci Technol. 2020;8:9-15. 